\title{
The Felix Meritis Concert Programs Database, 1832- 1888: From Archival Ephemera to Searchable Performance Data
}

\section{Arts and Media}

\author{
Mascha van Nieuwkerk (corresponding author) \\ University of Amsterdam, Amsterdam, Netherlands \\ maschavannieuwkerk@gmail.com
}

\author{
Harm Nijboer \\ University of Amsterdam, Amsterdam, Netherlands \\ harm.nijboer@huygens.knaw.nl
}

\author{
Ivan Kisjes \\ University of Amsterdam, Amsterdam, Netherlands \\ i.kisjes@uva.nl
}

\begin{abstract}
The Felix Meritis Concert Programs Database 1832-1888 (FMCP Database) provides a full digitisation of the concert programs collection of the most long-standing Dutch concert hall in the nineteenth century: Felix Meritis. Formerly hidden in boxes with archival ephemera, the content of this collection is now unlocked by manually entering the program details into a searchable dataset. The programs give an extremely rich account of a local concert practice, the performed repertoire, and the musicians involved. However, archiving concert programs at item-level presents a challenge: due to inconsistencies in and incompleteness of work descriptions it is often hard to identify and categorize the musical works performed. For the FMCP database, the authors have developed a possible solution to this problem; a strategy for structuring and categorizing concert programming data that aims to include incomplete work descriptions and reflect genre categorizations used in local concert practice. In this paper, the authors will present this categorization method and discuss the attributes and the basic structure of the FMCP database.
\end{abstract}




\section{Keywords}

concert - music - genre - repertoire - performance data - Netherlands - relational database

- Related data set "Felix Meritis Concert Programs Database" with DoI https://www.doi.org/10.17026/dans-2Z9-m5ng in repository "DANs"

- See the showcase of the data in the Exhibit of Datasets: https://www.dans datajournal.nl/rdp/exhibit.html?showcase=nieuwkerk2020a

\section{Introduction}

Music historians have only just begun to discover the full research potential of the thousands of concert programs that are scattered across European archives and libraries (Weber, 2000; Lee, 2017; Ridgewell, 2010; Bashford, 2008; Lloyd, 2003). In various fields of music historical research concert programs have proven to be extremely useful to enhance our understanding of the historical musical practice. In particular, performance data is often a missing link in studies that pursue a bottom-up approach to music history: studies into socioeconomic aspects of concert life, networks, patterns of taste, local repertoires and the implications of changing musical ideas for local musical practices (e.g. Pasler, 1993; Johnson, 1995; Weber, 2001 and 2009; Hall-Witt, 2007; Bashford, 2008; English, 2014).

Most concert programs, however, are tucked away in collections of concert ephemera that lack item-level cataloguing. Recently, there have been some great efforts to digitize concert programming data in London (Dix, Cowgill, Bashford, McVeigh, \& Ridgewell, 2014; Ridgewell, 2010), Paris (Campos \& Poidevin, 2011) and Prague (Stapleton, 2010). But these pioneering projects face a challenge that is inherent to this type data: due to inconsistencies in and incompleteness of work descriptions on the programs, it is often hard to identify and categorize the musical works performed (Lee, 2008 and 2017; Lloyd 2003). Therefore large parts of the data remain hidden for structural analysis of specific trends such as the development of repertoires and programming practices.

For the database presented here, we developed a possible solution to this challenge that can be transmitted to similar datasets. Based on principles from literary genre theory (Todorov, 1990; Jauss, 1982; Frow, 2007; Dubrow, 2014; Hernadi, 1972) we developed a strategy for structuring and categorizing concert programming data in a manner that reflects the locality and temporality 
of the genre categorizations used on the programs. Before we explain this further, let us first introduce the database; a fully-searchable digital transcription of the concert programs collection of the most long-standing Dutch concert hall in the nineteenth century: Felix Meritis.

\section{The Felix Meritis Concerts}

Felix Meritis was founded in 1777 as a private society for members of the local bourgeois elite who wanted to explore the arts and sciences. Society members were invited to attend weekly lectures and scientific demonstrations as well as a monthly Friday-evening concert. Starring famous musicians and singers from home and abroad accompanied by the Felix Meritis orchestra, the concerts became a popular meeting place for the political, social and cultural elite of nineteenth-century Amsterdam (Gompes \& Ligtelijn, 2007).

The long century (1777-1888) of Felix Meritis spans a period of dramatic changes in European musical life. All over Europe old exclusive venues and salons had to make way for public concert halls and professional orchestras took over from the once so active dilettante players. The symphonic 'absolute' music acquired an unmatched status and romanticism brought along new musical ideas and techniques, filling the minds of music lovers with extraordinary chords, melodies and sounds (Bonds, 2006; Dahlhaus, 1989b; Taruskin, 2006; Weber, 2009).

As a result of these transformations, the small, exclusive hall of Felix Meritis gradually became outdated, and eventually, in 1888, had to make way for a new public concert hall that could meet the latest demands: the Concertgebouw (van Nieuwkerk, 2011 and 2014). The programs of the Felix Meritis concerts give a unique insight into the musical practices in the Dutch capital in the 'pre-Concertgebouw-era'.

\section{Digitization and Data Structure}

- Felix Meritis Concert Programs Database deposited at DANS - DoI:https:// www.doi.org/10.17026/dans-2zg-m5ng

- Visualizing musical genres as networks

- Manual for data use with explanation and examples at CREATE - URL: https://www.create.humanities.uva.nl/blog/visualizing-musical-genres -as-networks

- Temporal coverage: $183^{2-1888}$ 
The Felix Meritis concert programs database 1832-1888 (FMCP Database) is the outcome of a one-year pilot project (2015-16), funded by the CREATE research program of the University of Amsterdam. The aim of the project was threefold: first, to design a data structure that reflects the specific ontology of a concert program; second, the actual input of the programming details into this data structure; and finally, to develop a historically informed genre taxonomy that helps users to categorize the musical works performed, even if works are completely unknown and/or can not be identified.

Since the source material was too messy to use automatic optical character recognition (OCR), the programs were manually transcribed using a special data entry interface designed by CREATE data specialist Harm Nijboer. Both the structure of the database and the data entry interface were designed to retain the original program descriptions, including inconsistencies, errors, and the genre indications on the programs. Reproducing these irregularities was essential for two reasons: first, the actual work descriptions and changing genre indications are central to the historical analysis of programming practices; and second, normalization would be impossible or arbitrary for many ambiguous or incomplete work descriptions.

Five basic elements of the concert programs are used to structure the data (see Figure 1): (1) persons (names of composers, musicians etc. often with their date of birth and death) can be found in table: persons; (2) the role of these persons in the particular program (composer, arranger, translator, cellist, flutist etc.) table: ref_person_roles; (3) the work description or title as mentioned on the program (verbatim_title); (4) locations that are mentioned such as the residency of performers or the place of origin of a musical theme (ref_locations); and (5) genre indications in the work descriptions (ref_genre_work_description; ref_genre_related; ref_genre_orginal_work; ref_genre_program_function). The multiple genre categories will be explained further below.

In the main table of the database (program_items) musical works with their composers and genre are grouped in ranked items for every event, so that the original order of the program is preserved and can be subject to analysis. A relational table (items2persons) links persons (singers, instrumentalists, translators, arrangers etc.) to these program items including their ref_person_ role (instrument or role in the performance as arranger or translator), their gender and sometimes their residency (location). Furthermore, there is a junction table linking items2genres. The junction table items_themes2locations gives an overview of program_items of which the verbatim_title explicitly refers to a location. It connects a location from the table ref_locations to an item_id. For example, item_id 1610 with verbatim_title 'Fantaisie op Russische en Schotse Thema's voor de Violoncel' is connected to the location_ids 129 and 127 (Russia and Scotland). 


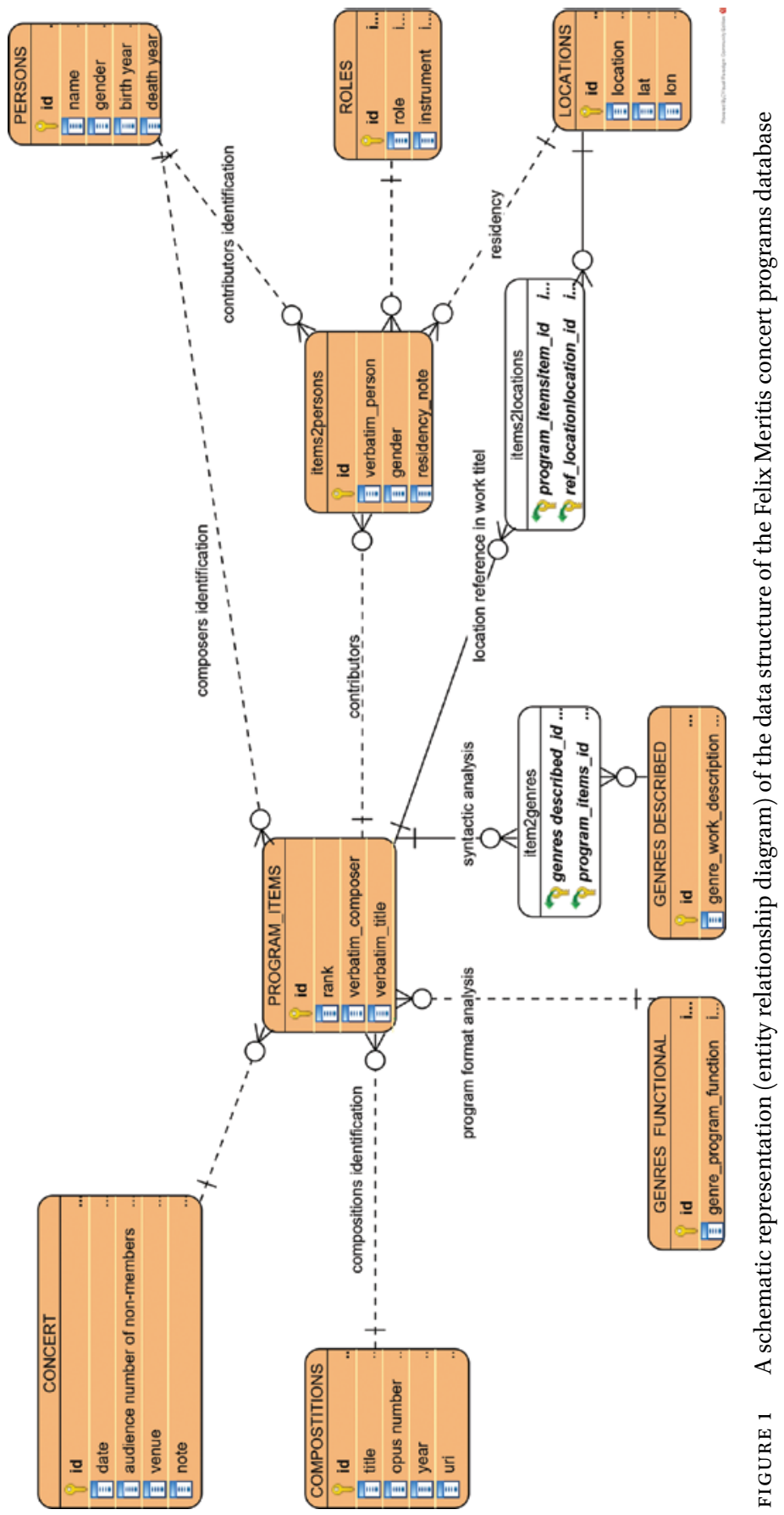


A snapshot of the data is currently deposited in EASY, the long-term data archiving system of the Dutch Archiving Network Service, DANs. As part of the CREATE program, the data will eventually be published as linked open data to be able to link the data to related datasets.

\section{Coverage}

At present, the FMCP Database contains a total of 701 programs with 6,582 descriptions of musical works. The database includes the programs of the regular subscription concerts organized by the Felix Meritis society under the artistic leadership of the conductors of the Felix Meritis orchestra.

The monthly Friday-evening concerts took place between September and April. The number of concerts organized by Felix Meritis varied between twenty concerts a year in the heydays of the society and eight or ten concerts in the last years of its existence. Access was restricted to members of the society, although they could introduce their wives, sons and guests from outside Amsterdam if they wished to.

Not included are concerts in the hall of Felix Meritis that were organized by external institutions or entrepreneurs, like the Maatschappij tot bevordering der Toonkunst and Caecilia. Likewise, one will not find the Sunday-afternoon chamber music concerts that Julius Röntgen organized starting from 1878 in this dataset.

The FMCP Database includes all concert programs that have been preserved in print. That is the programs of the period $183^{2-1871}$ and $1881-1888$. The printed programs of the years $1872-1880$ and the seasons before 1832 have been lost. Handwritten copies have been found recently but those copies are often incomplete and transcribing them is time-consuming. Eventually, these programs should be added to the dataset but we lacked the capacity to make this happen within this pilot project.

\section{Musical Mash-up}

The concert programs in this database are quite different from today's 'classical music' concerts. A concert at Felix Meritis typically offered a 'miscellany' of eight to a dozen pieces, alternating between symphonic and vocal repertoire, opera selections and virtuoso instrumental works. Consequently, the FMCP database documents an enormously varied repertoire ranging from popular classics by Beethoven and Mendelssohn to forgotten works by composers like Theodor Pixis and Alexander Batta that are scarcely documented elsewhere. 
TABLE 1 Program formats under the leadership of the three most longstanding conductors of the Felix Meritis orchestra

\begin{tabular}{lll}
$\begin{array}{l}\text { Johannes Bernardus van Bree } \\
\mathbf{1 8 3 0 - 1 8 5 6}\end{array}$ & $\begin{array}{l}\text { Johannes Verhulst } \\
\mathbf{1 8 6 4 - 1 8 8 6}\end{array}$ & $\begin{array}{l}\text { Julius Röntgen } \\
\mathbf{1 8 8 6 - 1 8 8 8}\end{array}$ \\
\hline- Overture/Symphony & - Symphony & - Overture \\
- Vocal aria & - Vocal aria & - Vocal aria/song \\
- Solo concerto & - Solo concerto & - Short instrumental \\
- Vocal aria & - intermission & work/solo concerto \\
- intermission & - Overture & - intermission \\
- Overture & -2 short instrumental & - Symphony \\
-2 short instrumental works & works & \\
-2 songs/vocal arias & -2 songs/vocal arias & \\
- Overture & - Overture &
\end{tabular}

How to make sense of this musical mash-up? William Weber, a pioneer in concert programming studies, has observed patterns in the miscellaneous programming practices of the early nineteenth century. His analysis of thousands of concert programs from all over Europe shows that in many cases concert programs can be understood as fixed sequences of certain clusters of works. He calls these clusters 'genres', from the German musicological tern 'Gattung'. Particular types of concerts with particular social functions had their particular sequences of genres, some emphasizing diversity, others presenting a more homogeneous repertoire (Weber, 2009).

In the case of Felix Meritis, such fixed programming formats were common practice throughout the nineteenth century. Different conductors in charge of the society's orchestra introduced their format for the regular programs (see Table 1). These genre sequences offer a useful starting point for a structural analysis of the programs. We will explore this further below.

\section{Musicians and Composers}

In the FMCP Database, one can find hundreds of musicians and unknown composers whose careers and oeuvres have scarcely been documented. The data reveal a European network of probably one of the most cosmopolitan professions of the nineteenth century. Musicians were travelling all around $\mathrm{Eu}-$ rope to give concerts and teach at conservatories and music schools. They 
TABLE 2 Repertoire performed by flautist H. M. van Boom on the concerts in Felix Meritis

\section{Concertos}

Berbiguier Concertante voor twee Fluiten

Bree, J. B. van Concertino voor twee Fluiten, gecomponeerd voor H. M. van Boom en P. C. Stadnitski

Drouet $\quad 12 \mathrm{e}$ Concert voor de Fluit

Furstenau Concertante voor twee Fluiten

Kummer Concertino voor Twee Fluiten

Kummer Concert voor twee Fluiten

\section{Fantasies and variations}

Boom, H. M. van Fantaisie voor de Fluit

Drouet Variatien voor de Fluit op het Jagerkoor uit de Opera het Vrijschot

Drouet Solo voor de Fluit, 'Sul Margine D'un Rio'

Drouet Le Ranz des Vaches, Fantaisie voor Piano Forte en Fluit

Drouet Variations sur l'Air favori O Dolce Contento, de Mozart, voor Zang en Fluit

Furstenau Fantasie voor twee Fluiten

Tulou Fantaisie voor de Fluit

Tulou "Grande Fantaisie pour deux Flutes"

Other short instrumental works

Kalliwoda, J. W. Trio voor Fluit, Viool en Violoncel

Kuhlau Adagio en Rondo voor Piano Forte en Fluit

Tulou Nocturne voor Fluit en Harp

Arias and songs with flute obligato

Kummer, F. A. Le Rossignol, Romance, met accompagnement van Obligate Fluit Panseron Philomèle, Romance, met accompagnement van Obligate Fluit

Weber, von Ballade: Einsam bin ich nicht allein, met Obligate Fluit

Weber, von Romances uit Preciosa, met Obligate Fluit 


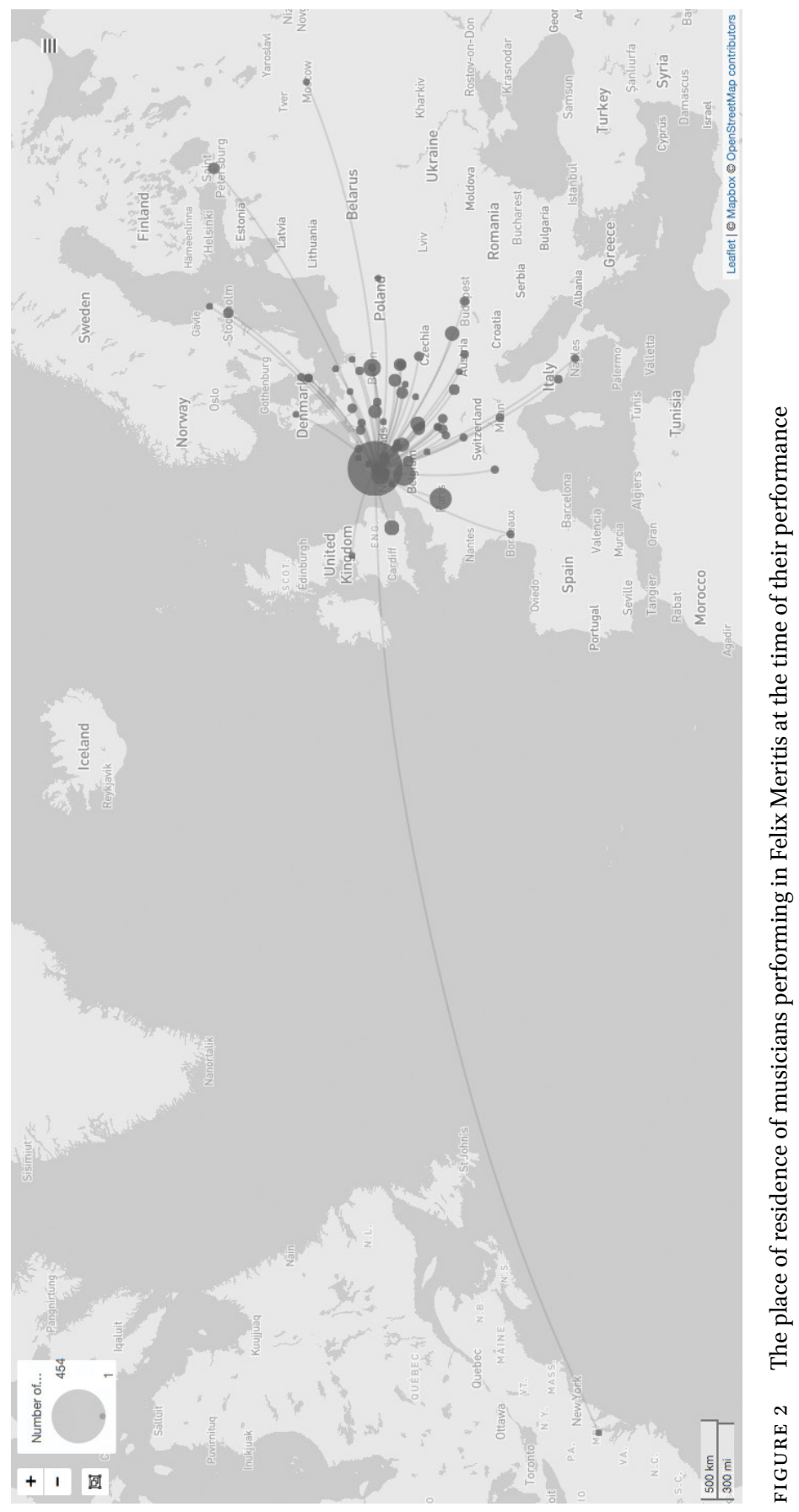


could communicate their musical backgrounds with great ease thanks to a shared European system of music notation and performance practice that transcended national(ist) styles and practices (Müller, 2007; Applegate, 2007).

Using the data from the FMCP Database we can follow these unknown musicians, their changing residencies (see Figure 1) and repertoires (see Table 2). Flautist Hermanus Marinus van Boom, for example, appeared 55 times on a

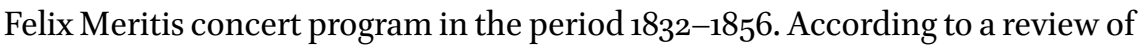
one of his concerts, he was a student of the French flautist Jean-Louis Tulou (Kist, 1853). He regularly performed fantasies and variations on famous opera melodies written by himself, his teacher and other flute players of his time. His repertoire and that of his colleagues give an insight into the way instrumentalists presented themselves to the audience by recomposing famous opera themes in creative and virtuoso ways (van Nieuwkerk, 2016).

On almost one-third of the programs, we found information about the place where a musician lived and worked at the time of their performance (see Figure 2; table: items2persons; persons_location). This information can eventually easily be combined with information in other online resources about the place of birth or death of composers and musicians. To give users quick access to these resources 469 of the 616 composers $(76 \%)$ in this database have been identified by linkage to external databases such as the International Music Score Library Project (IMSLP), Wikidata, VIAF and the Dutch Biographical Portal (table: uris). Identification has been done in batch by using string comparisons, which reduced the need for an item by item identification to a large degree (van Nieuwkerk \& Nijboer, 2016).

\section{Genre}

The descriptions of the musical works on the Felix Meritis concert programs are often ambiguous. For example, programs announce the performance of a 'Symphony' by Beethoven, a 'Melody' by Schubert or even 'Romances, with guitar accompaniment' without any indication of the composer. In these cases, it is not possible to identify which symphony or song is performed, but we do know the type or genre of the performed work and therefore it can still be part of our analysis.

In order to systematically analyze and categorize the repertoire in the FMCP Database, we developed a genre categorization method that reproduces the genre indications used on the actual programs. Instead of using an existing a-priori genre taxonomy based on 'Gattungstheorie' (Samson, 2001), we recreated a taxonomy based on the local and contemporary use of genre concepts. 
This historical approach to genre is mainly indebted to literary genre theory. Instead of pinpointing a genre as a theoretical entity, the starting point was to approach genres as historically changing categories: "classes of [artworks] that have been historically perceived as such" (Todorov, 1990, 17). Even more interesting for research into concert practice is the idea that genres are not just a means of 'classification' but rather of 'communication' (Hernadi, 1972; Rosmarin, 1985). By labelling a musical work on a program as part of a certain genre category, the attention of the listener is purposefully drawn to specific aspects of a piece (Kallberg, 1988). A genre gives listeners a necessary hint of what to expect in terms of duration, style, atmosphere and musical form. Sometimes it also gives an implicit hint about the instrumentation, although this is not always straightforward. For example, a symphony involves the orchestra and an aria is expected to be performed by a singer, but a fantasy can either be a piece for orchestra or a solo piece for any instrument with piano accompaniment.

Genre not only directs the audience expectations of a single musical work, but it could also be decisive for the order of the musical works on a concert program in the eighteenth- and nineteenth centuries. As mentioned in the previous section, programs were often based on fixed programming formats, fixed sequences of genres that were used as a blueprint for the order of musical works on a program. In these programming formats, certain classes of works had a specific function.

By analyzing programs in this way one can observe changes in programming formats over a longer time frame. For example, the conductors Van Bree and Verhulst regularly placed an overture as the opening of the second half, combined with some songs, short instrumental pieces and another closing overture. Röntgen, on the other hand, cleared the whole second half to place the symphony on a pedestal as the one and only work played after the intermission (van Nieuwkerk, 2016).

In order to make both the general function of a work within the programming format and the more detailed genre classifications used on the programs subject to analysis, we have created two classification systems. The first is a dictionary (ref_genre_program_function) based on the function of a work within the program sequence. In this taxonomy classes of works that had the same function or would be interchangeable on the program are grouped as one category. For example, a minuet, a polonaise and a nocturne are very different genres but they all functioned as 'short instrumental work', a short signature piece chosen by the instrumental soloist. Similarly, vocal romances, serenades and melodies all functioned as songs performed in the second half of the 
TABLE 3 Examples of work descriptions with genre indications in different constituents of the description

\begin{tabular}{|c|c|c|c|c|c|}
\hline Composer & Work description & $\begin{array}{l}\text { Genre program } \\
\text { function }\end{array}$ & $\begin{array}{l}\text { Key words: } \\
\text { Genre work } \\
\text { description } \\
\text { (noun) }\end{array}$ & $\begin{array}{l}\text { Related } \\
\text { genre } \\
\text { (adjective) }\end{array}$ & $\begin{array}{l}\text { Genre } \\
\text { original work } \\
\text { (preposition) }\end{array}$ \\
\hline Ernst & $\begin{array}{l}\text { Solo voor de Viool, } \\
\text { Caprice sur un thême } \\
\text { du Pirate, de Bellini }\end{array}$ & $\begin{array}{l}\text { Short } \\
\text { instrumental } \\
\text { work }\end{array}$ & Solo & Caprice & Opera \\
\hline Thomas & $\begin{array}{l}\text { Aria Polacca uit de } \\
\text { Opera Mignon }\end{array}$ & Vocal aria & Aria & Polonaise & Opera \\
\hline Mendelssohn & $\begin{array}{l}\text { Rondo Capricioso, } \\
\text { voor de Piano Forte }\end{array}$ & $\begin{array}{l}\text { Short } \\
\text { instrumental } \\
\text { work }\end{array}$ & Rondo & Caprice & \\
\hline
\end{tabular}

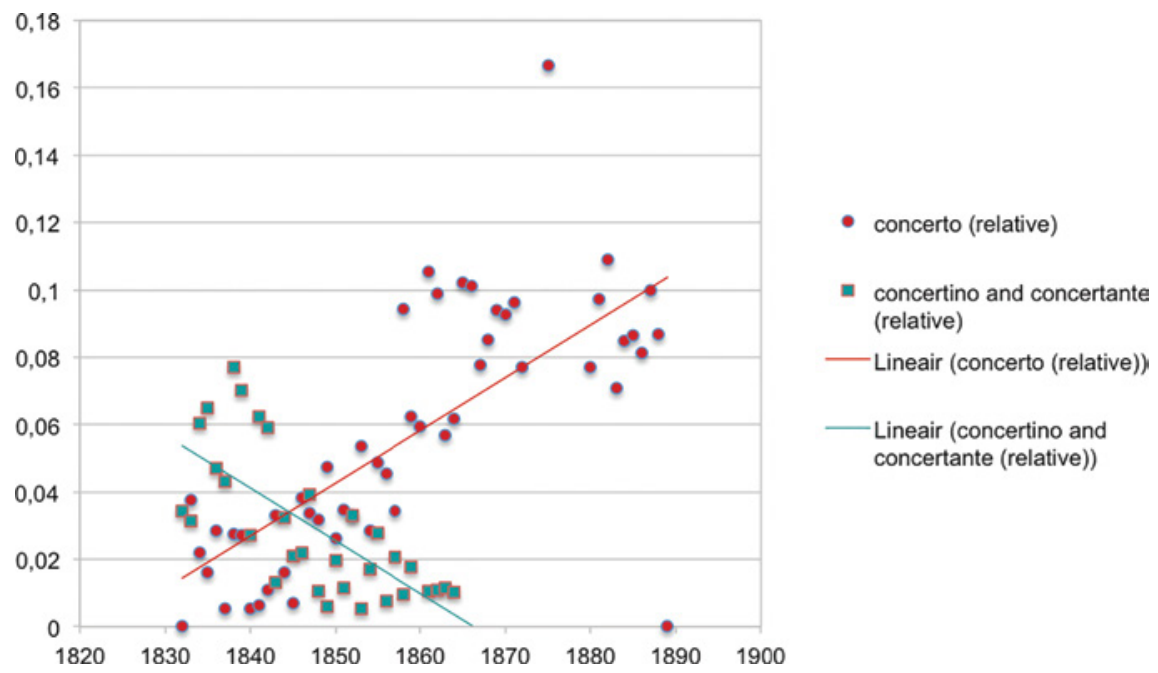

FIGURE 3 The occurrence of genres concertante/concertino and genre concerto in the period $183^{2-1888}$ 


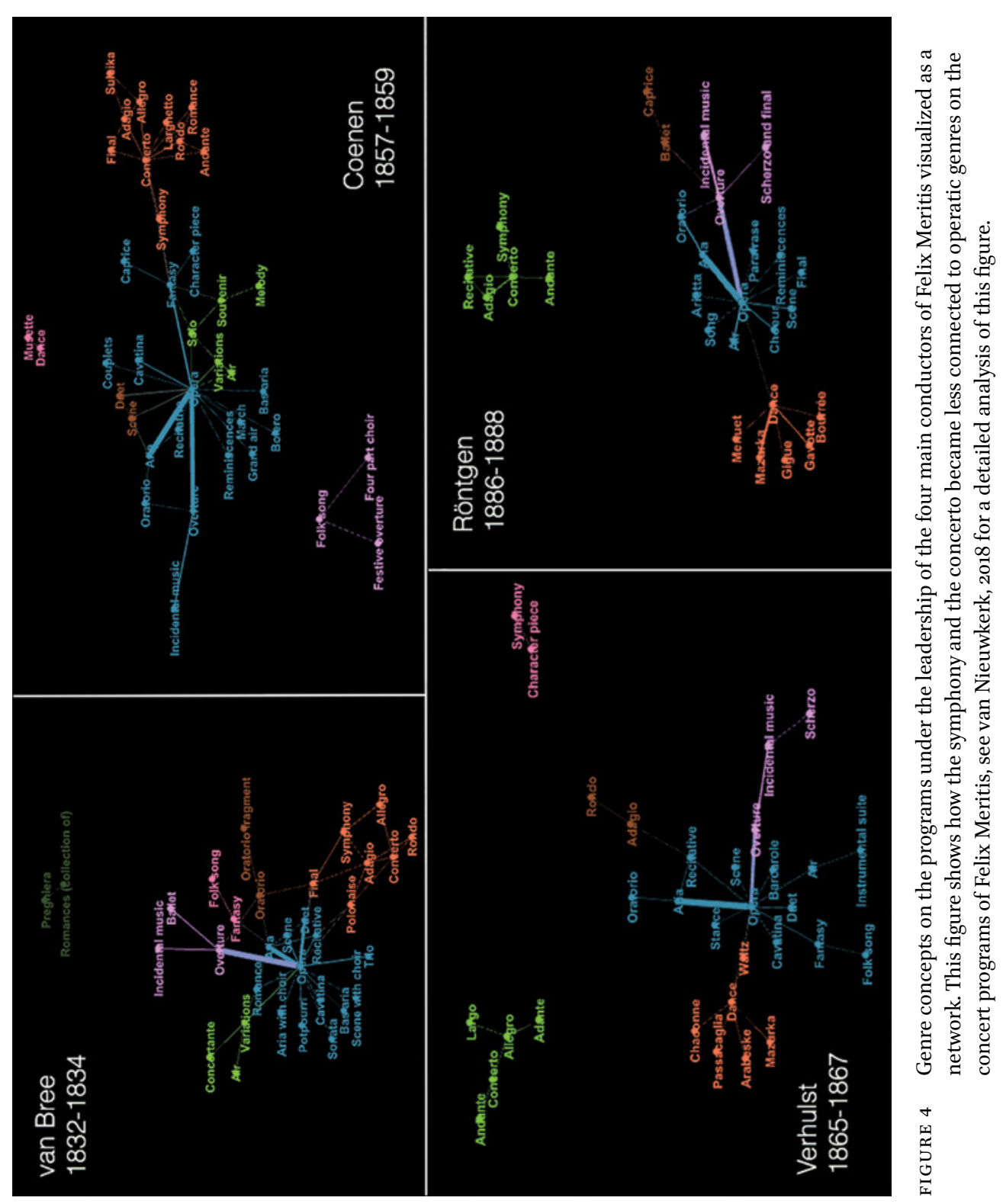


program before the concluding overture. These program functions help us to observe changes in programming formats and to identify deviant programs such as the format of Röntgen and other interesting periods of experiment (van Nieuwkerk, 2016). Indeed, this dictionary is based on the specific, temporal and local programming practices at Felix Meritis and should be reconsidered when analyzing or comparing programming practices in other places or periods.

The second classification (genre_work_description) is more flexible and therefore more complex. It is, in fact, a parsing method rather than a fixed dictionary. The categories that can be found in this table (ref_genre_work_ description; ref_related_genre and ref_genre_original_work) are based on a syntactic analysis of the genre descriptions on the programs. They relate to different constituents of the work description (See Table 3). Genre work description is the main genre mentioned in the work description; related genre refers to a genre concept that describes a secondary characteristic of the work, genre original work is the genre of the work from which the current work originates: the work is often a fragment, an arrangement or another type of musical adaptation.

\section{Concluding Remarks}

This categorization strategy for concert programming data has enormous potential for analyzing and comparing local concert practices. It reveals musical developments that would otherwise remain invisible, such as the extinction of old genres and the introduction of new ones (see Figure 3), changing relationships between genres (see Figure 4, and see van Nieuwkerk, 2016 and 2018) and changing program formats (see Table 1). By focusing on connections instead of distinctions between musical types, this approach furthermore revisits dominant theories about the alleged separation between operatic and instrumental genres in the nineteenth century (van Nieuwkerk, 2016; Dahlhaus, 1989a, 1989b and 2005). Both institutionally and in historiography opera and concert practice are often approached as separate musical spheres. The case of Felix Meritis shows how operatic fragments and arrangements retained a central place in local concert practice throughout the nineteenth century and how operatic works were transformed for the circumstances of their reception in the concert hall.

For more examples of how to work with this categorization system and guidelines for visualizing a local genre taxonomy as a network in Gephi, see: (van Nieuwkerk, 2018). 


\section{References}

Applegate, C. (2007). The Internationalism of Nationalism: Adolf Bernhard Marx and German music in the mid-nineteenth century. Journal of Modern European History, 5(1), 139-159. Retrieved from https://www.jstor.org/stable/26265845.

Bashford, C. (2008). Writing (British) concert history. The blessing and curse of ephemera. Notes, $64(3), 5^{8-473}$.

Bonds, M. E. (2006). Music as thought. Listening to the symphony in the age of Beethoven. Princeton, NJ: Princeton University Press.

Campos, R., \& Poidevin, A. (2011). Les archives des institutions musicales Parisiennes (1918-1969). Fontes Artis Musicae, 58(1), 72-84.

Dahlhaus, C. (1989a). New music and the problem of musical genre. In D. Puffett \& A. Clayton (Trans.), Schoenberg and the new music: Essays by Carl Dahlhaus (pp. 32-44). Cambridge \& New York, NY: Cambridge University Press.

Dahlhaus, C. (1989b). Nineteenth-century music. London: University of California Press.

Dahlhaus, C. (2005). Zur Problematik der musikalischen Gattungen im 19. Jahrhundert. In S. Mauser (Ed.), Theorie der Gattungen (pp. 193-230). Laaber: LaaberVerlag.

Dix, A., Cowgill, R., Bashford, R., McVeigh, S., \& Ridgewell, R. (2014). Authority and judgement in the digital archive. ACM International Conference Proceeding Series: DLfM ' 14 Proceedings of the ist International Workshop on Digital Libraries for Musicology (pp. 1-8). https://doi.org/10.1145/2660168.2660171.

Dubrow, H. (2014). Genre (Routledge Revivals). Abingdon \& New York, NY: Routledge.

English, H. (2014). Music-making in the colonial city. Benefit concerts in Newcastle, NSw in the 1870s. Musicology Australia, 36(1), 53-73. https://www.doi.org/10.1080/ 08145857.2014 .896071$.

Frow, J. (2007). "Reproducibles, rubrics, and everything you need": Genre theory today. PMLA, 122(5), 1626-1634. Retrieved from https://www.jstor.org/stable/25501811.

Gompes, L. \& Ligtelijn, M. (2007). Spiegel van Amsterdam: Geschiedenis van Felix Meritis. Amsterdam: Stichting Felix Meritis \& Rozenberg Publishers.

Hall-Witt, J. (2007). Fashionable acts. Opera and elite culture in London, 1780-1880, Durham NH: University of New Hampshire Press \& Hanover, NH: University Press of New England.

Hernadi, P. (1972). Beyond genre. New directions in literary classification. Ithaca, NY: Cornell University Press.

Jauss, H. R. (1982). Toward an aesthetic of reception. Minneapolis, MN: University of Minnesota Press.

Johnson, J. H. (1995). Listening in Paris. A cultural history. Berkeley \& Los Angeles: University of California Press. 
Kallberg, J. (1988). The rhetoric of genre. Chopin's Nocturne in g minor. 19th-Century Music, 11(3), 238-261.

Kist, C. (1853). H. M. van Boom. Caecilia: algemeen muzikaal tijdschrift van Nederland, 10 (18: 15-09-1853), 106.

Lee, D. (2008). Classifying musical performance: the application of classification theories to concert programmes. (MA thesis in Information Service Management, London Metropolitan University). http://dx.doi.org/10.17613/M6FH70.

Lee, D. (2017). Modelling music: a theoretical approach to the classification of notated Western art music. (Unpublished Doctoral thesis, City, University of London). http://openaccess.city.ac.uk/id/eprint/17445.

Lloyd, S. (2003). Ephemera of concert life: Programmes and press cuttings. In L. Foreman (Ed.), Information sources in music (pp. 337-36o). München: Saur.

Müller, S. (2007). Einleitung: Musik als nationale und transnationale Praxis im 19. Jahrhundert. Journal of Modern European History, 5(1), 22-38. Retrieved from https:// www.jstor.org/stable/26265840.

Pasler, J. (1993). Concert programs and their narratives as emblems of ideology. International Journal of Musicology, 2, 249-308.

Ridgewell, R. (2010). The Concert Programmes Project: history, progress and future directions. Fontes Artis Musicae, 57(1), 50-64.

Rosmarin, A. (1985). The power of genre. University of Minnesota Press.

Samson, J. (2001). Genre. Grove Music Online. Retrieved 12 Sep. 2018, from http://www.ox fordmusiconline.com/grovemusic/view/10.1093/gmo/9781561592630.001.0001/omo -9781561592630-e-0000040599.

Stapleton, K. (2010). Prague concert life 1850-1881. An annotated database. Fontes Artis Musicae, 57(1), 1-22.

Taruskin, R. (2006). The Oxford history of Western music, vol. 3: Music in the nineteenth century. Oxford [etc.]: Oxford University Press.

Todorov, T. (1990). Genres in discourse. (C. Porter, Trans.). Cambridge \& New York, NY: Cambridge University Press.

van Nieuwkerk, M. (2011). Van Felix Meritis naar het Concertgebouw. Continuïteit en vernieuwing in de Amsterdamse concertpraktijk, 1884-1891. Skript Historisch Tijdschrift, 33(4), 228-241.

van Nieuwkerk, M. (2014). Muziektempel van een vervlogen tijd. De ondergang van Felix Meritis als leidende concertzaal van Amsterdam 1864-1888 (Unpublished Bachelor Thesis). University of Amsterdam, Amsterdam. Retrieved from http://www.mas chavannieuwkerk.com/wp-content/uploads/2014/03/Muziektempel-van-een-verv logen-tijd_Mascha-van-Nieuwkerk_preview.pdf.

van Nieuwkerk, M. (2016). Een vergeten repertoire. De concertprogrammering van Felix Meritis in de periode 1830-1888 (Unpublished Master Thesis). University of Amsterdam, Amsterdam. 
van Nieuwkerk, M. (2018). Visualizing musical genres as networks [Creative Amsterdam: an E-Humanities Perspective]. Retrieved November 13, 2018, from http:/ /www. create.humanities.uva.nl/blog/visualizing-musical-genres-as-networks/.

van Nieuwkerk, M., \& Nijboer, H. (2016, June). Nineteenth century concert programs in a digital research environment. The case of Felix Meritis. Poster presentation presented at the DH Benelux, Belval, Luxemburg.

Weber, W. (2000). Miscellany vs. homogeneity. Concert programmes at the Royal Academy of Music and the Royal College of Music in the 1880s. In C. Bashford \& L. Langley (Eds.), Music and British culture, 1785-1914: Essays in honour of Cyril Ehrlich (pp. 299-320). Oxford \& New York, NY: Oxford University Press.

Weber, W. (2001). From miscellany to homogeneity in concert programming. Poetics, $29(2), 125^{-134}$.

Weber, W. (2009). The great transformation of musical taste. Concert programming from Haydn to Brahms (1st edition). Cambridge [etc.]: Cambridge University Press. 